\title{
Differential activation of adipogenesis by multiple PPAR isoforms
}

\author{
Regina P. Brun, ${ }^{1}$ Peter Tontonoz, ${ }^{1}$ Barry M. Forman, ${ }^{2}$ Ramsey Ellis, ${ }^{1}$ Jasmine Chen, ${ }^{2}$ \\ Ronald M. Evans, ${ }^{2,3}$ and Bruce M. Spiegelman ${ }^{1,4}$ \\ ${ }^{1}$ Dana-Farber Cancer Institute and Department of Cell Biology, Harvard Medical School, Boston, Massachusetts 02115 USA; \\ ${ }^{2}$ Gene Expression Laboratory, The Salk Institute for Biological Studies, ${ }^{3}$ Howard Hughes Medical Institute, Gene Expression \\ Lab, La Jolla, California 92037 USA
}

Peroxisome proliferator-activated receptor $\gamma(\operatorname{PPAR} \gamma)$ is a nuclear hormone receptor expressed predominantly in adipose tissue, where it plays a central role in the control of adipocyte gene expression and differentiation. Because there are two additional PPAR isoforms, PPAR $\alpha$ and PPAR $\delta$, and these are also expressed at some level in certain adipose depots, we have compared directly the adipogenic potential of all three receptors. Ectopically expressed PPAR $\gamma$ powerfully induces adipogenesis at a morphological and molecular level in response to a number of PPAR $\gamma$ activators. PPAR $\alpha$ is less adipogenic but is able to induce significant differentiation in response to strong PPAR $\alpha$ activators. Expression and activation of PPAR $\delta$ did not stimulate adipogenesis. Of the three PPARs, only PPAR $\gamma$ can cooperate with $\mathrm{C} / \mathrm{EBP} \alpha$ in the promotion of adipogenesis. To begin to investigate the functional basis for the differential adipogenic activity of the PPAR isoforms, we have examined their ability to bind to several PPAR DNA response sequences. Compared with PPAR $\alpha$ and PPARס, PPAR $\gamma$ shows preferential binding to two well-characterized regulatory sequences derived from a fat-specific gene, ARE6 and ARE7. These data strongly suggest that PPAR $\gamma$ is the predominant receptor regulating adipogenesis; however, they also suggest that PPAR $\alpha$ may play a role in differentiation of certain adipose depots in response to a different set of physiologic activators or in certain disease states.

[Key Words: Adipogenic activity; PPAR isoforms; nuclear hormone receptor; adipose tissue; gene expression; differentiation]

Received December 22, 1995; accepted in revised form February 23, 1996.

As a central component of the energy balance system, adipocytes store triglycerides in periods of nutritional abundance and release free fatty acids in times of caloric deficiency. Obesity, an excessive development of adipose tissue, affects $\sim 30 \%$ of all adults in the United States. This disorder is a major health problem, representing a significant risk factor for non-insulin-dependent diabetes mellitus, coronary artery disease, and hypertension. Thus, new approaches to the prevention and treatment of these disorders may result from a thorough understanding of the molecular aspects of adipocyte differentiation and lipogenesis.

Several recent advances have led to new insights in the molecular control of adipogenesis and adipocyte-specific gene expression. One important advance has come from the analysis of the tissue-specific enhancer from the adipocyte P2 (aP2) gene (Ross et al. 1990; Graves et al. 1991). The key transcriptional regulator of this enhancer was identified as a novel activity termed ARF6 (Graves et al. 1992). This same factor was also identified as a regulator of the PEPCK gene (Tontonoz et al. 1994b). The

${ }^{4}$ Corresponding author. observation that the ARF6 DNA-binding sequence was similar to the DR-1-type hormone response element led to the identification of a member of the nuclear hormone receptor family, peroxisome proliferator-activated receptor $\gamma 2$ (PPAR $y 2$ ), which is expressed at high levels specifically in adipose tissue. PPAR $\gamma$ binds to and activates transcription through DR-1 sites in a heterodimeric complex with retinoid $X$ receptor $\alpha(\mathrm{RXR} \alpha)$ (Kliewer et al. 1994; Tontonoz et al. 1994a, b). The PPAR $\gamma$ gene contains two promoters that produce two isoforms, PPAR $\gamma 1$ and PPAR $y 2$, via differential splicing (Zhu et al. 1995). Expression and activation of PPAR $\gamma 1$ or PPAR $y 2$ in fibroblasts is sufficient to trigger the adipocyte differentiation cascade (Tontonoz et al. 1994c).

The adipogenic potential of members of the CCAAT/ enhancer-binding protein $|\mathrm{C} / \mathrm{EBP}\rangle$ family has also been studied intensively. Although expression of the C/EBPs is not restricted to fat, they are expressed at high levels in this tissue and are induced during adipogenesis /Cao et al. 1991). C/EBP $\alpha$ has been demonstrated to bind and trans-activate the promoters of a number of adipocyte genes (Ntambi et al. 1988; Christy et al. 1989, 1991; Herrera et al. 1989; Park et al. 1990; Christy et al. 1991; Cornelius et al. 1994). In addition, C/EBP $\alpha$ was shown to 
play an important role in terminal differentiation of preadipocytes (Samuelsson et al. 1991; Umek et al. 1991; Lin and Lane 1994). Although $\mathrm{C} / \mathrm{EBP} \alpha$ is not expressed until relatively late in the time course of adipogenesis (Cao et al. 1991), ectopic expression of $\mathrm{C} / \mathrm{EBP} \alpha$ can convert fibroblastic cells to adipocytes (Freytag et al. 1994). Recently, C/EBPß, which is expressed early in the differentiation process (Cao et al. 1991), has also been shown to induce adipocyte differentiation (Yeh et al. 1995), possibly through the induction of PPAR $\gamma$ (Wu et al. 1995). Because the promoters of several fat-specific genes contain both C/EBP-and PPAR-binding sites, it is likely that members from both families cooperate in the transcription of many fat cell-specific genes/Christy et al. 1989; Herrera et al. 1989; Park et al. 1990; Tontonoz et al. 1994a, 1995). Recent experiments have shown that PPAR $\gamma$ and $\mathrm{C} / \mathrm{EBP} \alpha$ promote differentiation synergistically, allowing adipogenesis in the absence of exogenously added PPAR $\gamma$ activator (Tontonoz et al. 1994c). This combination of PPAR $\gamma$ and $C / E B P \alpha$ is so powerfully adipogenic it causes the transdifferentiation of determined myoblasts into fat cells (Hu et al. 1995).

Three PPAR isoforms have been identified that define a subfamily of nuclear hormone receptors. The PPARs contain highly conserved DNA-binding domains but more divergent ligand-binding domains (Kliewer et al. 1994). Thus, although they bind to the same consensus DR-1 DNA sequences in vitro, the activation profiles of these three receptors are pharmacologically distinct. $\operatorname{PPAR} \alpha$, expressed mainly in heart, liver, and kidney, is thought to regulate transcription of many genes involved in lipid metabolism, especially the enzymes involved in the $\beta$-oxidation of fatty acids (Gottlicher et al. 1992; Gulick et al. 1994; Krey et al. 1995; Lee et al. 19951. Although PPAR $\alpha$ is not expressed at significant levels in white fat, it is expressed in brown fat (Isseman and Green 1990; Beck et al. 1992). PPARס, also referred to as NUC-1 (Schmidt et al. 1992) and FAAR (Amri et al. 1995), is expressed in nearly all tissues (Kliewer et al. 1994; Tontonoz et al. 1994c; Amri et al. 1995) and has been re- ported to regulate expression of some fat-specific genes (Amri et al. 1995). As its expression appears to be induced with the cessation of cell growth at confluence, it has been suggested that PPAR $\delta$ may play a significant role in the adipogenic process (Amri et al. 1995). Although the other PPAR isoforms remain orphan receptors, ligands for PPAR $\gamma$ have been identified recently that are potent inducers of adipogenesis in vitro. These include thiazolidinediones, a class of antidiabetic drugs, and the arachidonic acid derivative 15 -deoxy- $\Delta^{12,14}$-prostaglandin $\mathrm{J}_{2}$ (15d-J2) (Forman et al. 1995; Kliewer et al. 1995; Lehmann et al. 1995l.

As all of the PPAR isoforms are expressed to some degree in certain fat depots, we have examined directly the adipogenic potential of the three PPAR isoforms when expressed in fibroblasts. Although PPAR is the most adipogenic member of this family, we find that PPAR $\alpha$ is also capable of promoting adipocyte differentiation in response to strong PPAR $\alpha$ activators. PPAR $\delta$ did not stimulate adipogenesis even in response to the strongest PPAR $\delta$ activators. Only PPAR $\gamma$ showed marked synergy with $\mathrm{C} / \mathrm{EBP} \alpha$ to activate the adipogenic program. These results may be at least partially explained by a preferential binding of PPAR $\gamma$ to non-consensus PPAR response elements (PPRE) found in certain fat cell-specific genes.

\section{Results \\ PPAR isoforms can be distinguished pharmacologically}

To assess the adipogenic potentials of the three PPAR isoforms, we first characterized the activation profile of each of the receptors (Fig. 1). Each PPAR was transfected into CV-1 cells and assayed for its ability to activate multiple copies of a PPRE placed upstream of a luciferase reporter gene. As reported previously, the peroxisome proliferator Wy 14,643 efficiently activates $\operatorname{PPAR} \alpha$, but not PPAR $\gamma$ or PPAR (Kliewer et al. 1994). In contrast,

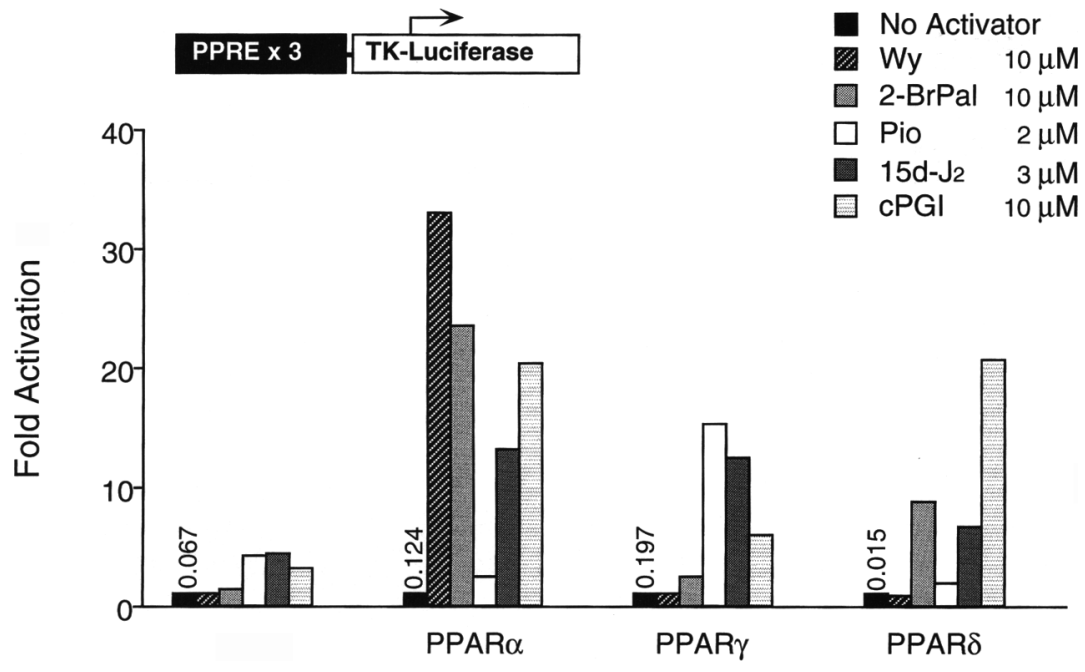

Figure 1. Transcriptional activation of the PPAR isoforms by PPAR activators. The reporter construct contains three copies of the acyl-CoA oxidase PPRE cloned upstream of the TK-LUC reporter. CV-1 cells were transfected with the PPRE 3 TK-LUC reporter $\left(300 \mathrm{ng} / 10^{5}\right.$ cells), CMX-PPAR $\alpha, C M X-P P A R \gamma$, or CMX$\operatorname{PPAR} \delta$ (100 ng/ $10^{5}$ cells), and the internal control, CMX- $\beta$-gal $\left(500 \mathrm{ng} / 10^{5}\right.$ cells). Cells were treated for $40 \mathrm{hr}$ with media containing the indicated compounds. Normalized luciferase activity was determined and plotted as fold activation relative to untreated cells. The absolute value of luciferase units for the untreated controls is indicated. (Wy) Wy 14,643; (2BrPal) 2-bromopalmitate; (pio) pioglitazone; (15d-J2) 15-deoxy- $\Delta^{12,14}$-prostaglandin 2 ; (CPGI) carbacyclin. 
pioglitazone, a thiazolidinedione that has been shown to be a ligand for PPAR $\gamma$ (Forman et al. 1995; Lehmann et al. 1995), efficiently activates only PPAR $\gamma$. The other activators examined did not demonstrate such a marked isoform specificity. 15d-J2, which has also been shown to bind directly to PPAR $y$ (Forman et al. 1995; Kliewer et al. 1995), also activates the $\alpha$ and $\delta$ isoforms. 2-Bromopalmitate, a stable form of a dietary fatty acid, has been reported to be an efficient activator of PPAR $\delta$ (Amri et al. 1995). As shown in Figure 1, this compound also activates the other two receptors.

Prostacylin is known to possess many biological activities, including the promotion of adipogenesis (Catalioto et al. 1991; Vassaux et al. 1992). These effects are thought to be mediated by binding to a cell surface receptor (Namba et al. 1994) and the activation of cAMP and $\mathrm{Ca}^{2+}$ second messenger pathways (Vassaux et al. 1995). The recent identification of $15-\mathrm{d} J 2$ as a ligand for PPAR $\gamma$ raises the possibility that other arachidonate metabolites might also function as activators of PPARs. We have found that carbacyclin, a stable analog of prostacy. clin, is an effective activator of all three PPAR isoforms and may be the most efficacious activator of PPAR $\delta$ identified to date.

\section{Adipogenic action of the three PPARS}

We used retroviruses to express the three PPARs in $\mathrm{fi}$ broblastic cells. It is beneficial to use a retroviral system in differentiation studies, as it allows similar levels of ectopic gene expression of a construct in hundreds of thousands of cells and avoids the isolation of individual clones. This is extremely important because individually selected fibroblastic clones exhibit tremendous variability in their ability to undergo adipogenesis (Green and Kehinde 1976). This retroviral system has been used previously to investigate the biological function of PPARy (Tontonoz et al. 1994c) and C/EBPB (Yeh et al. 1995). The pBabe-Puro expression vectors containing the $\mathrm{cD}$ NAs encoding PPAR $\alpha, \operatorname{PPAR} \delta$, and PPAR $\gamma$ were packaged into virus, and the resulting viral stocks were used to infect NIH-3T3 cells (Tontonoz et al. 1994c). In this manner, stable cell lines were isolated that contained the parental expression vector (NIH-vector) or that expressed PPAR $\alpha$ (NIH-PPAR $\alpha)$, PPAR $\gamma(\mathrm{NIH}-\operatorname{PPAR} \gamma)$, or PPAR (NIH-PPAR $\delta$ ).

As shown in Figure 2A, each retroviral construct is expressed at significant levels in NIH-3T3 cells. In NIHPPAR $\gamma$ cells, the viral transcript encoding PPAR $\gamma$ (lane 2) is produced at approximately one-third the level of endogenous PPAR $\gamma$ observed in fully differentiated adipocytes (lane 1). NIH-3T3 cells do not normally express significant levels of PPAR $\gamma$ (lane 5). NIH-PPAR $\alpha$ cells (lane 3) express much more PPAR $\alpha$ mRNA than is expressed in 3T3-Ll adipocytes (lane 1) or NIH-vector cells (lane 5). PPAR $\delta$ mRNA is expressed in fully differentiated adipocytes at approximately the same level as in $\mathrm{NIH}$-vector cells (lanes 1,5). The retroviral expression vector increases this level of PPAR $\delta$ expression by threeto four-fold (lane 4). Western blot analysis reveals that
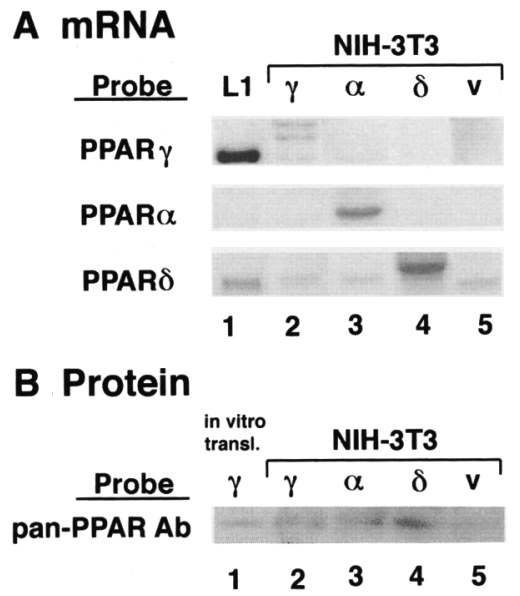

Figure 2. Endogenous and ectopic expression of PPAR isoforms in NIH-3T3 cells and 3T3-L1 adipocytes. NIH-3T3 cells were infected with retroviruses carrying $\mathrm{pBabe}$-derived expression vectors as described in Materials and methods. (A) Total RNA $(15 \mu \mathrm{g} /$ lane) was isolated from virally transduced NIH3T3 cells and differentiated 3T3-L1 adipocytes, electrophoresed, transferred to nylon membranes, and hybridized with ${ }^{32} \mathrm{P}$ labeled PPAR $\gamma, \operatorname{PPAR} \alpha$, and PPAR $\delta$ cDNA. An equivalent amount of intact RNA was run in each lane, as indicated by hybridization to a 36B4 cDNA probe (data not shown). (B) Western blot analysis of nuclear extracts $(50 \mu \mathrm{g} /$ lane) from virally transduced NIH-3T3 cells (lanes 2-4) was subjected to SDSPAGE, transferred to membrane, and probed with an anti-PPAR antibody that recognizes all three isoforms (Affinity Bioreagents). (Lane 1 In vitro-translated PPAR $\gamma$.

the protein level of each of the PPAR isoforms is similar (Fig. 2B). In addition, expression of all three PPAR isoforms results in a similar increase in PPRE-binding activity in extracts from these cell lines (data not shown).

These cell lines were then cultured under conditions permissive for adipogenesis. At confluence, they were treated with various PPAR activators, and after 7 days, they were fixed and stained for accumulated neutral lipid with Oil Red O. Macroscopic examination of the stained dishes demonstrated that NIH-PPAR $\gamma$ cells readily accumulated lipid when treated with pioglitazone, 2-bromopalmitate, 15d-12 or carbacyclin (Fig. 3). Pioglitazone, a direct ligand of PPAR $\gamma$, stimulated the most abundant lipid accumulation. PPAR $\alpha$-expressing cells also accumulated considerable stainable lipid when treated with the highly efficacious PPAR $\alpha$ activators 2-bromopalmitate or carbacyclin. Wy14,643 also clearly induced lipid accumulation, although this was somewhat less than seen with 2-bromopalmitate and carbacyclin. However, chronic treatment of cells with this agent was accompanied by signs of toxicity, including the detachment of many cells. Little or no lipid accumulation in the PPAR $\alpha$ cells was observed in response to either of the known PPAR $y$ ligands pioglitazone or $15 \mathrm{~d}-J 2$. In contrast to the other two receptors, lipid accumulation was not observed in NIH-PPAR $\delta$ cell cultures regardless of the activator used. Even carbacyclin, which was the most effective inducer of the transcriptional activity of PPAR $\delta$ 


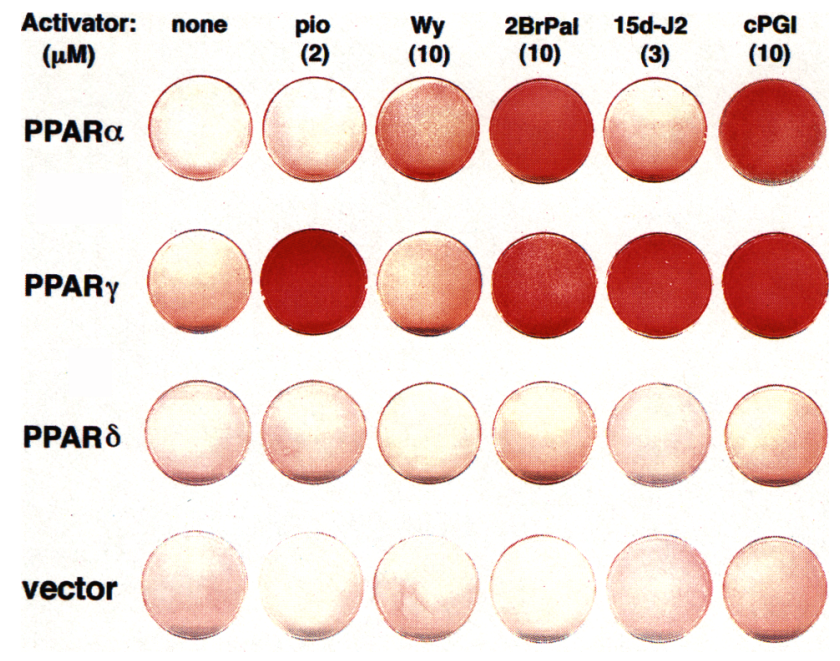

Figure 3. PPAR $\gamma$ and PPAR $\alpha$ stimulate adipogenesis in NIH$3 \mathrm{~T} 3$ cells. Stable NIH-PPAR $\alpha, \mathrm{NIH}-\mathrm{PPAR} \gamma, \mathrm{NIH}-\mathrm{PPAR} \delta$, and $\mathrm{NIH}$-vector cell lines were cultured in differentiation media (see Materials and methods) with the indicated concentration of PPAR activator. Macroscopic views of cells are shown that were fixed and stained with Oil Red $\mathrm{O}$ after 7 days of confluent culture. $(\mathrm{Wy}) \mathrm{Wyl4}, 643$; (2BrPal) 2-bromopalmitate; (pio) pioglitazone; (15d-J2) 15-deoxy- $\Delta^{12,14}$-prostaglandin $\mathrm{I} 2$; (cPGI) carbacyclin.

(Figure 1) and which promoted differentiation in the $\operatorname{PPAR} \gamma$ - and PPAR $\alpha$-expressing cells, failed to promote differentiation through PPAR $\delta$. NIH-vector cells failed to undergo adipogenesis in response to any activator.

Microscopic examination of differentiated NIHPPAR $\gamma$ (Fig. 4C) and NIH-PPAR $\alpha$ (Fig. 4B) cells revealed a morphological appearance characteristic of cultured adipocytes, with many small lipid droplets seen in the cytoplasm. However, the NIH-PPAR $\gamma$ cells generally exhibited more extensive differentiation, reflected both in the amount of lipid accumulated in each cell and the percentage of cells that accumulated lipid $180 \%-95 \%$ for $\operatorname{PPAR} \gamma$ in eight experiments versus $30 \%-60 \%$ for PPAR $\alpha$ in eight experiments). The time course of differentiation of the PPAR $\alpha$ cells also appeared slower than that seen with cells expressing PPAR $\gamma$ (see below). NIHPPAR $\delta$ cells and NIH-vector cells retained a fibroblastic morphology under all conditions examined (Fig. 4A). These experiments were performed with at least five different cell lines generated by retroviral infection for each receptor.

To characterize the differentiated state of the cells at a molecular level, Northern analysis was performed on RNA isolated at two time points in the differentiation process (Fig. 5). In the experiment shown, $\sim 90 \%$ of the PPAR $y$ cells treated with pioglitazone had differentiated morphologically, as compared with $60 \%$ of the PPAR $\alpha$ cells treated with 2-bromopalmitate or carbacyclin. When examined after 5 days of treatment with pioglitazone, 2-bromopalmitate, or 15d-J2, NIH-PPARy cells had induced expression of many adipocyte-specific genes, including endogenous PPAR $\gamma$, adipsin, and aP2
(Fig. 5A). However, no or very little induction of these genes was seen in the PPAR $\alpha$ cells at this time point (Fig. $5 \mathrm{~A})$. After 7 days of treatment with various PPAR activators, both NIH-PPAR $\gamma$ and NIH-PPAR $\alpha$ cells expressed high levels of mRNA for endogenous PPAR $\gamma$, adipsin, and aP2 (Fig. 5B). At this time point, NIHPPAR $\gamma$ and NIH-PPAR $\alpha$ differentiated cells also express similar levels of mRNA for lipoprotein lipase, ADD1, and acyl coenzyme A (acyl-CoA) synthase (data not shown). Thus, the pattern of gene expression of both NIH-PPAR $\gamma$ and NIH-PPAR $\alpha$-differentiated cells indicate a bona fide adipogenic process. These data are also consistent with the morphological evidence suggesting that differentiation directed by PPAR $\alpha$ may occur at a slower rate than differentiation directed by PPAR $\gamma$.

Significant levels of adipsin or PPAR $y$ were not detected in $\mathrm{NIH}$-vector or NIH-PPAR $\delta$ cells under any condition, even after a week of treatment with PPAR activators (Fig. 5B). A longer exposure of the films shown in Figure 5 revealed low levels of aP2 mRNA in NIHPPAR $\delta$ cells that were treated for 7 days with 2-bromopalmitate and carbacyclin, the compounds that activated PPAR $\delta$ most effectively (Fig. 5C). aP2 expression was also stimulated in NIH-vector cells treated with carbacyclin, albeit to a lesser extent. This may be attributable to the normal, low level of PPAR $\delta$ or PPAR $\gamma$ expression in NIH-3T3 cells or to another biological effect of carbacyclin. These data demonstrate that PPAR $\delta$ can stimulate some expression of aP2 mRNA but does not appear to be capable of fully activating the adipocyte differentiation program.

\section{$C / E B P \alpha$ cooperates with PPAR $\gamma$, but not PPAR $\alpha$ or PPAR $\delta$, to induce adipogenesis}

Expression of both C/EBP $\alpha$ and PPAR $\gamma$ in fibroblasts allows powerful differentiation in the absence of added PPAR activators (Tontonoz et al. 1994c). This implies that forced expression of $\mathrm{C} / \mathrm{EBP} \alpha$ in fibroblasts overrides the need to provide PPAR $\gamma$ activators exogenously. The cooperation between PPAR $\gamma$ and $\mathrm{C} / \mathrm{EBP} \alpha$ may be very important in the adipogenic process, as both factors are present in most adipocytes examined. We have investigated whether PPAR $\alpha$ and PPAR $\delta$ can also cooperate with C/EBPa. Using a retroviral construct which contained the C/EBP $\alpha$ CDNA and a neomycin-selectable marker (Tontonoz et al. 1994c), NIH-3T3 cells were sequentially infected with retroviruses to generate cell lines that expressed $\mathrm{C} / \mathrm{EBP} \alpha$ and one of the PPAR isoforms. These cells were cultured for 7 days after confluence under conditions permissive for adipogenesis but without exogenously added PPAR activators. Macroscopic views of the Oil Red O-stained dishes are shown in Figure 6A. As demonstrated by lipid accumulation, $\mathrm{NIH}-\mathrm{C} / \mathrm{EBP} \alpha$ cells differentiated into adipocytes at a low but detectable level. Coexpression of PPAR $\gamma$ with $\mathrm{C} / \mathrm{EBP} \alpha$ strikingly increased the degree of differentiation. Coexpression of PPAR $\alpha$ or PPAR $\delta$ with C/EBP $\alpha$ did not appear to increase the level of differentiation induced 
Brun et al.

Figure 4. Morphological differentiation through PPAR expression. Stable NIHPPAR $\alpha$, NIH-PPAR $\gamma$, and NIH-PPAR $\delta$ cell lines were cultured in differentiation media (see Materials and methods) with their most efficacious PPAR activator for 7 days postconfluence. NIH-PPAR $\alpha$ cells were treated with $10 \mu \mathrm{M}$ 2-bromopalmitate $|B|$, NIH-PPAR $y$ cells were treated with $2 \mu \mathrm{M}$ pioglitazone $(C)$, and NIH-vector $(A)$ and NIH-PPAR $\delta(D)$ cells were treated with 100 $\mu \mathrm{M}$ 2-bromopalmitate. Cells were then fixed and stained with Oil Red O. Microscopic views of cells at $40 \times$ magnification are shown.

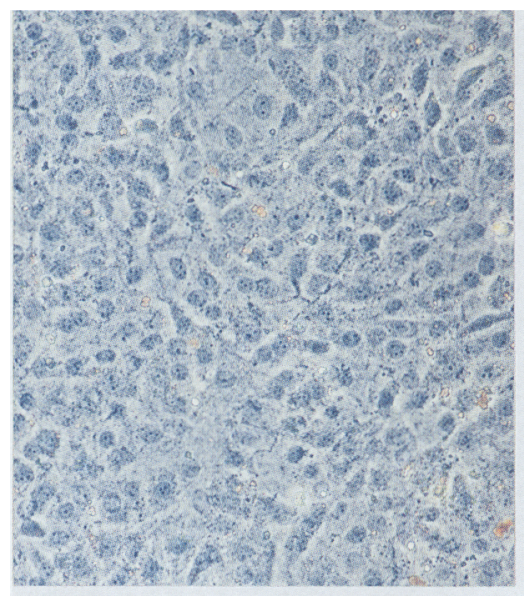

A

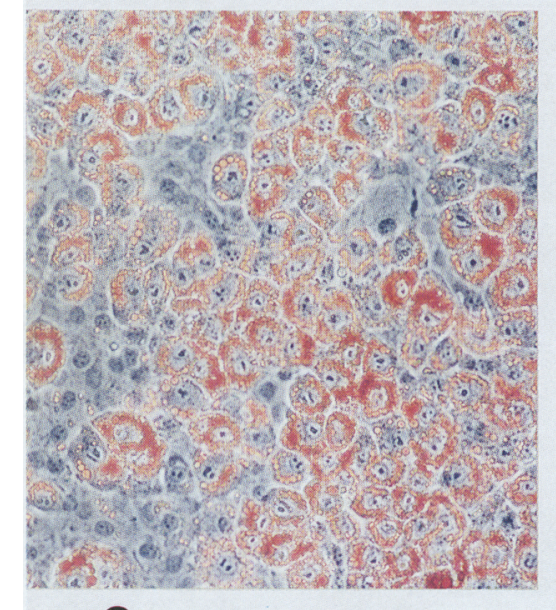

C NIH-PPAR $\gamma$

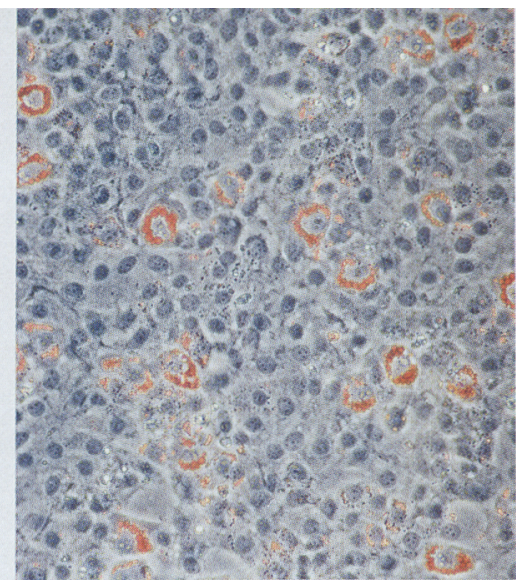

B NIH-PPAR $\alpha$

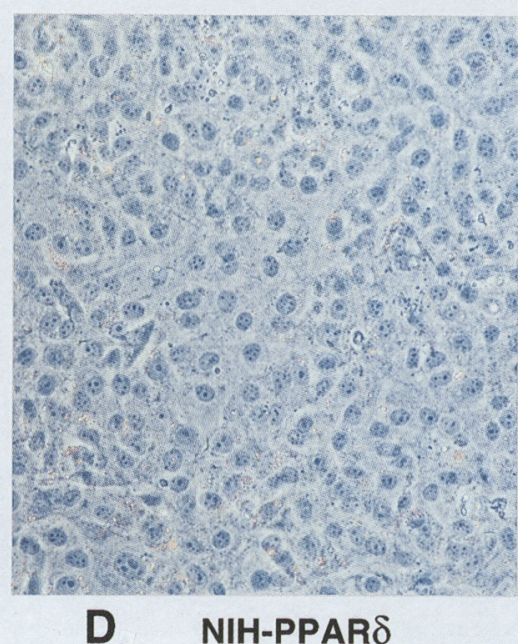

by $\mathrm{C} / \mathrm{EBP} \alpha$ alone. PPAR $\alpha$ and PPAR $\delta$ actually appeared to have an inhibitory effect.

The expression of adipocyte-specific genes in these cell lines was consistent with the morphologic data (Fig. 6B). NIH-C/EBP $\alpha$ cells expressed elevated levels of adipocyte-specific genes (lane 2) when compared to cells transfected with only the parental expression vectors (lane 1). Coexpression of PPAR $\gamma$ markedly increased the expression of all adipocyte marker genes examined (lane 4). However, neither PPAR $\alpha$ nor PPAR $\delta$ had this effect. In fact, coexpression of PPAR $\delta$ actually inhibited expression of endogenous PPAR $\gamma, \mathrm{aP} 2$, and especially adipsin, when compared to cells transfected with only the $\mathrm{C} / \mathrm{EBP} \alpha$ expression vector (lane 5). PPAR $\alpha$ likewise inhibited the induction of these marker genes, albeit to a lesser extent (lane 3). Thus, only PPAR $\gamma$ demonstrates the ability to cooperate with $\mathrm{C} / \mathrm{EBP} \alpha$ in the induction of adipogenesis, at least under these experimental conditions. These data indicate that while PPAR $\alpha$ possesses some adipogenic potential, PPAR $\gamma$ is a more effective inducer of adipocyte differentiation in combination with $\mathrm{C} / \mathrm{EBP} \alpha$.
PPAR $y$ has higher affinity for fat-specific PPREs than PPAR $\alpha$ or PPAR $\delta$

All three PPAR isoforms have highly conserved DNAbinding domains and bind to the same consensus DR-1 sequences. However, the possiblity that the three receptors possess differences in DNA-binding characteristics has not been thoroughly explored. To determine whether differences in DNA binding might contribute to the differential adipogenic activity shown by the PPAR isoforms, we tested by electorphoretic mobility shift assay the ability of each isoform to bind to two regulatory DR1-type elements present in the fat-specific enhancer of the aP2 gene (Graves et al. 1992; Tontonoz et al. 1994a), a functional DR-1 sequence present in an enhancer of the liver-specific acyl-CoA oxidase gene (Tugwood et al. 1992) and an ideal consensus DR-1 sequence.

Of these DNA sequences, each PPAR isoform demonstrated the strongest binding to the optimal, consensus DR-1 element (PPRE-op). The binding of each PPAR isoform to the AOX sequence was similar to its binding of the PPRE-op (Fig. 7B). The binding of all three isoforms 

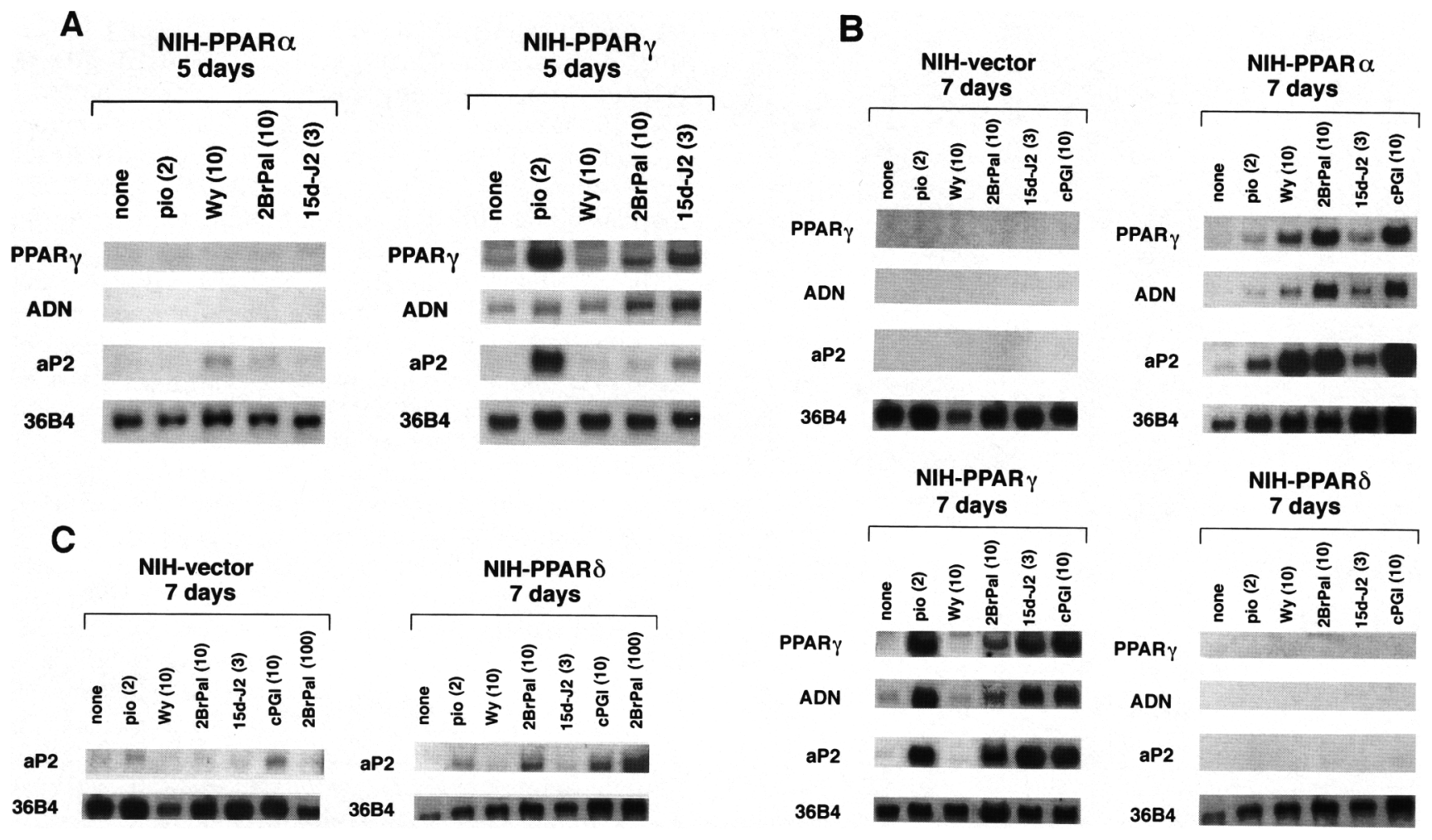

Figure 5. Induction of adipocyte-specific gene expression by PPAR isoforms. $(A)$ NIH-PPAR $\alpha$ and NIH-PPAR $\gamma$ cells were treated as in Fig. 3 with the indicated concentration of PPAR activator for 5 days after confluence. Total RNA (15 $\mu \mathrm{g} / \mathrm{lane}$ ) was isolated, electrophoresed, blotted onto nylon membranes, and hybridized with the indicated ${ }^{32}$ P-labeled cDNA probes. An equivalent amount of intact RNA was run in each lane as indicated by hybridization to a $36 \mathrm{~B} 4$ probe. $|B| \mathrm{NIH}$-vector, NIH-PPAR $\alpha, \mathrm{NIH}-\mathrm{PPAR} \gamma$, and NIH-PPAR $\delta$ cells were treated as in Fig. 3 with the indicated concentration of PPAR activator for 7 days after confluence. Total RNA (15 mg/lane) was isolated, electorphoresed, blotted onto nylon membranes, and hybridized with the indicated ${ }^{32} \mathrm{P}$-labeled cDNA probes. $(C)$ The filters hybridized with aP2 from $B$ were exposed for $15 \mathrm{hr}$, vs. $3 \mathrm{hr}$ in $B$, to show induction of low levels of aP2 expression. (Wy) Wy 14,643; (2BrPal) 2-bromopalmitate; (pio) pioglitazone; (15d-J2) 15-deoxy- $\lrcorner^{12,14}$-prostaglandin I2; (cPGI) carbacy$\mathrm{clin}_{;}(\mathrm{ADN})$ adipsin; $(\mathrm{aP2})$ adipocyte fatty acid-binding protein; $|36 \mathrm{~B} 4|$ human acid ribosomal phosphoprotein PO.

to the ARE6 and ARE7 oligonucleotides was decreased compared with the other two sequences (Fig. $7 \mathrm{C}, \mathrm{D}$ ). Although the nonconsensus, fat-specific elements are less optimal binding sites for all of the PPARs, PPAR y clearly shows a higher affinity for ARE6 and ARE7 relative to the other two isoforms. When normalized to binding on the consensus site, PPAR $\gamma$ shows a two-fold higher binding to the ARE7 site compared with PPAR $\alpha$ or PPAR $\delta$ (Fig. 7C). The binding of PPAR $y$ to ARE6, which is even more divergent from the consensus DR-1 sequence, was 2.5-fold higher than PPAR $\delta$ and 4-fold higher than PPAR $\alpha$ (Fig. 7D). This suggests that the differences in adipogenic potential between PPAR $\alpha$ and PPAR $\gamma$ may be at least partially attributable to differences in the ability to bind to DR-1 sequences of some fat regulatory genes.

\section{Discussion}

Roles in adipogenesis have been suggested for all three mammalian PPAR isoforms. To date, the only datum addressing this issue directly is the demonstration that $\operatorname{PPAR} \gamma$, when expressed and activated in fibroblasts, ef- ficiently induces the adipocyte differentiation program (Tontonoz et al. 1994c). A role for PPAR $\alpha$ in adipogenesis has been suggested by the observation that a PPAR $\alpha$ selective activator stimulates terminal differentiation of 3T3-Ll preadipocytes (Yu et al. 1995). Studies using thiazolidinediones to stimulate adipogenesis have suggested that PPAR $\delta$ plays an important role in this process (Teboul et al. 1995). Given these data, it is important to assess directly the ability of all three isoforms to induce adipocyte differentiation by expressing and activating each of the receptors in fibroblastic cells. We observed previously that PPAR $\alpha$ could induce aP2 expression but could not activate the differentiation cascade in response to the weak PPAR $\alpha$ activator ETYA (Tontonoz et al. 1994c). Using the highly efficacious PPAR $\alpha$ activators Wy14,653, 2-bromopalmitate, or carbacyclin, we now show that PPAR $\alpha$ is capable of initiating the adipocyte program. Fibroblasts expressing PPAR $\alpha$ undergo morphologic changes, accumulate lipid, and induce expression of an array of adipocyte-specific genes when treated with very efficient activators of this receptor. In contrast, expression and activation of PPAR $\delta$ in these experiments did not cause adipogenesis. The expression 


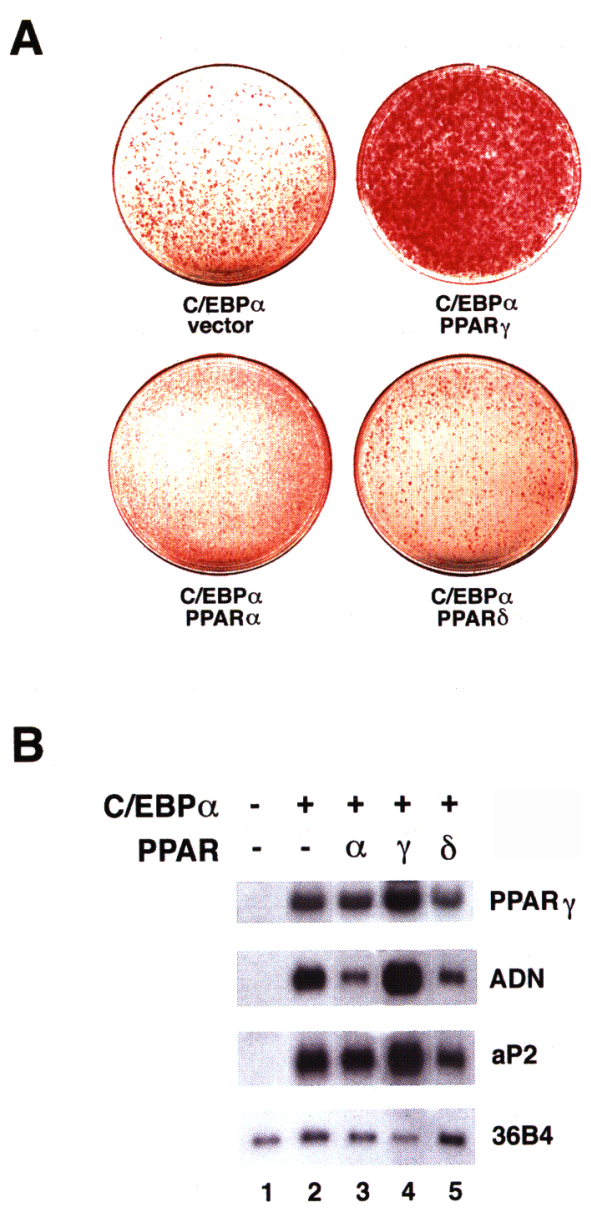

Figure 6. Cooperation of PPAR isoforms with C/EBP $\alpha .|A|$ $\mathrm{NIH}-\mathrm{C} / \mathrm{EBP} \alpha /$ vector, NIH-C/EBP $\alpha / \mathrm{PPAR} \gamma, \mathrm{NIH}-\mathrm{C} / \mathrm{EBP} \alpha /$ PPAR $\alpha$, and NIH-C/EBP $\alpha /$ PPAR $\delta$ stable cell lines were cultured in differentiation media containing $1 \mu \mathrm{M}$ dexamethasone for 7 days postconfluence. Macroscopic views of cells which were fixed and stained with Oil Red O are shown. $(B)$ Total RNA from stable cell lines cultured as described in $A$ was isolated, electrophoresed, blotted to nylon membrane, and hybridized with the indicated ${ }^{32} \mathrm{P}$-labeled cDNA probes. An equivalent amount of intact RNA was run in each lane as indicated by hybridization to a $36 \mathrm{~B} 4$ probe. (ADN) Adipsin; (aP2) adipocyte fatty acid-binding protein; (36B4) human acid ribosomal phosphoprotein PO.

of PPAR $\delta$ actually reduces the level of adipogenesis promoted by C/EBP $\alpha$ expression.

It has been shown recently that overexpression of $\mathrm{C} / \mathrm{EBP} \beta$ activates adipogenesis in a manner dependent on PPAR $\gamma$ activity (Wu et al. 1995). Because adipocytes derived from PPAR $\alpha$-expressing cells express PPAR $\gamma$, it is possible that PPAR $\alpha$ stimulates differentiation through the expression of PPAR $\gamma$. Three lines of evidence argue against this possibility. First, PPAR $\alpha$-induced differentiation does not require the addition of an exogenous PPAR $\gamma$ activator. As seen in Figures 3-5, treatment with Wy14,643, which does not activate PPAR $y$ and had no effect on NIH-PPAR $\gamma$ cells, stimu- lates adipogenesis in NIH-PPAR $\alpha$ cells. Second, induction of endogenous PPAR $\gamma$ expression in NIH-PPAR $\alpha$ cells does not occur particularly early in the course of differentiation, as has been demonstrated with overexpression of C/EBP $\beta$ (Wu et al. 1995). Endogenous PPAR $\gamma$ expression seems to be induced by PPAR $\alpha$ with the other markers of the adipocyte differentiation program (Fig. 5). Finally, addition of pioglitazone, a PPAR $\gamma$-specific activator, to NIH-PPAR $\alpha$ cells treated with Wy14,643 did not further stimulate lipid accumulation or adipocyte specific gene expression early in the differentiation process (data not shown). Some effect of pioglitazone was observed only relatively late in the differentiation process, after induction of endogenous PPAR $\gamma$.

Although PPAR $\alpha$ activates the differentiation program, it appears to do so less efficiently than PPAR $\gamma$. PPAR $\gamma$ induces differentiation in response to diverse PPAR $y$ activators, even those that are not particularly strong activators of its transcriptional activity, such as carbacyclin and 2-bromopalmitate. PPAR $\alpha$-directed differentiation, on the other hand, only occurs in the presence of the strongest PPAR $\alpha$ activators. In addition, the differentiation induced by PPAR $\alpha$ is less extensive in terms of the percentage of cells undergoing differentiation, the amount of lipid accumulated, and also occurs at a slower rate compared to that driven by $\operatorname{PPAR} \gamma$. As shown in Figure 7, the PPARs do differ in their relative binding to divergent sequences that still may be considered DR-1-type elements. Hence, this could underlie some of the differences in adipogenic activity among these receptors. This is supported by the fact that PPAR $\gamma$ possesses higher affinity for two nonconsensus, DR-1type sequences present in a fat specific enhancer (from the aP2 gene) compared to the other receptors. The notion that the DNA-binding characteristics of the PPARs may contribute to differences in adipogenic potential may be definitively determined by studying chimeric receptors that switch DNA-binding domains.

Cooperation between the C/EBP and PPAR families is likely to play an important role in the process of adipocyte differentiation. Several fat-specific genes have been shown to contain binding sites for both PPARs and C/EBPs (Christy et al. 1989; Herrera et al. 1989; Park et al. 1990; Tontonoz et al. 1994a, 1995). We have shown here that only PPAR $y$ is able to cooperate with C/EBP $\alpha$ to induce adipogenesis in the absence of exogenously added PPAR activator. This suggests a special relationship between these two factors that does not appear to exist between $\mathrm{C} / \mathrm{EBP} \alpha$ and the other two receptors. There are several possible explanations, which are not mutually exclusive, for this cooperative interaction. One is that $\mathrm{C} / \mathrm{EBP} \alpha$ and PPAR $\gamma$ synergistically activate a factor in the basal transcriptional machinery. Another possibility is that there is a direct protein-protein interaction between PPAR $\gamma$ and C/EBP $\alpha$ that increases the activity of either or both factors. The observation that the PPAR isoforms have subtle DNA-binding site preferences raises the possibility that PPAR $\alpha$ does not synergize with $\mathrm{C} / \mathrm{EBP} \alpha$ because it is unable to interact with $\mathrm{C} / \mathrm{EBP} \alpha$ on the promoters of some important, fat-specific 
A

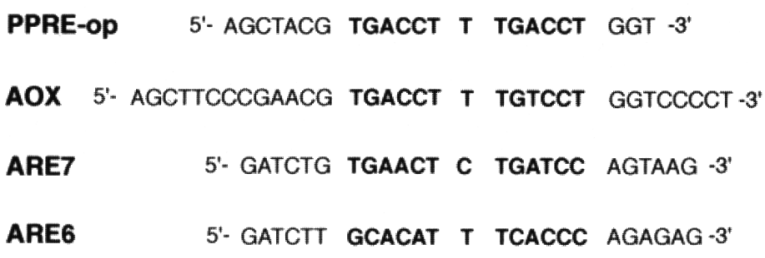

ARE6
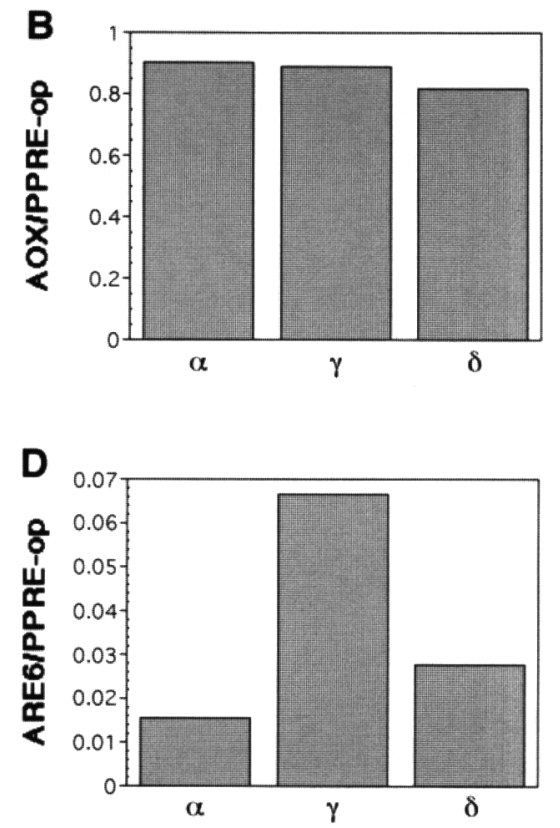

Figure 7. Binding of PPAR isoforms to different DR-1 sequences. $|A|$ Sequences (top strand only) of double-stranded oligonucleotides that were radiolabeled and used as probes in EMSA with in vitro-translated RXR $\alpha$ and equal amounts of in vitro-translated PPAR $\alpha$, PPAR $\gamma$, or PPAR $\delta$. Nucleotides of the DR-1-type sequence are in boldface type. Amounts of specifically bound acyl CoA oxidase PPRE $(B)$ and the aP2 enhancer elements ARE7 $|C|$ and ARE6 $(D)$ were quantitated and normalized to bound PPRE-op for each isoform. (PPRE-op) Consensus PPRE; (AOX) acyl CoA oxidase PPRE.

genes. Alternately, the lack of cooperativity between $\mathrm{C} / \mathrm{EBP} \alpha$ and PPAR $\alpha$ might suggest that the region of PPAR $\gamma$ that interacts with $\mathrm{C} / \mathrm{EBP} \alpha$ is not conserved in $\operatorname{PPAR} \alpha$. Finally, as these receptors are pharmacologically distinct, $\mathrm{C} / \mathrm{EBP} \alpha$ may regulate genes involved in the production of a ligand that activates only PPAR $\gamma$. Thus, coexpression of PPAR $\gamma$ and C/EBP $\alpha$ could lead to differentiation in the absence of added PPAR $\gamma$ activator, but $\mathrm{C} / \mathrm{EBP} \alpha$ expression would not necessarily result in the efficient activation of PPAR $\alpha$. Although the exact nature of the cooperativity between $\mathrm{C} / \mathrm{EBP} \alpha$ and PPAR $\gamma$ remains to be elucidated, it appears to be specific to the $\gamma$ isoform.

It has also been postulated that PPAR $\delta$ plays a prominent role in the activation of adipogenesis (Amri et al. 1995; Teboul et al. 1995). These reports suggest that PPARס mediates induction of adipocyte-specific gene expression in fibroblasts and adipogenesis in myocytes in response to treatment with 2-bromopalmitate and thiazolidinediones, respectively. In this study we have directly addressed the potential role of this receptor in adipogenesis by overexpressing and activating PPAR $\delta$ in fibroblasts. No evidence of adipocyte differentiation was observed in NIH-PPAR $\delta$ cells under any condition, including treatment with thiazolidinediones and 2-bromopalmitate. Both of these compounds efficiently induced differentiation in fibroblasts expressing PPAR $\gamma$. Furthermore, we and others have reported that PPAR $\gamma$, and not PPAR $\delta$, directly binds and is activated by thiazolidinediones (Forman et al. 1995; Lehmann et al. 1995). Taken together, these data suggest that the reported ef- fects of 2-bromopalmitate and thiazolidinediones are not attributable to the activation of PPAR $\delta$, but, rather, are probably the results of activation of the low levels of PPAR $\gamma$ present in these cell lines. However, it still remains possible that much more potent and efficacious activators of PPAR $\delta$ might reveal some adipogenic action of this receptor that cannot be revealed with the compounds currently available.

Previous studies have shown that the stable prostacyclin analog carbacyclin can promote the differentiation of cultured adipocytes (Catalioto et al. 1991; Vassaux et al. 19921. We demonstrate here that carbacyclin is an activator of all three known mammalian PPARs and is the best activator of PPAR $\delta$ described to date. Although some biological effects of prostacyclin are known to be mediated by its cell-surface receptor (Namba et al. 1994), our results suggest that the ability of this compound to promote differentiation may be mediated by nuclear PPARs. As the prostanoid $15 \mathrm{~d}-12$ recently has been demonstrated to promote adipogenesis by binding directly to PPAR $\gamma$ (Forman et al. 1995; Kliewer et al. 1995), our results raise the possibility that carbacyclin may also bind directly to one or more PPARs.

Although the physiological meaning of the finding that PPAR $\alpha$ can be adipogenic is not clear, it may lie in the heterogeneity of adipose cells. Mammalian organisms possess at least two distinct types of adipose tissue, white and brown. Whereas the main function of white fat is to store energy and mobilize it in times of nutritional deficiency, brown fat plays an important role in theromogenesis. Brown fat expresses the mitochondrial 
uncoupling protein (UCP), which allows the cell to dissipate energy in the form of heat rather than generate ATP. The molecular basis underlying the decision to differentiate into brown or white fat is not understood. Interestingly, brown fat is known to expresses both PPAR $\alpha$ (Isseman and Green 1990; Beck et al. 1992), and PPAR $\gamma$ (P. Tontonoz and B.M. Spiegelman, unpubl.). This is one of the few known differences in gene expression between white and brown fat. Thus, although PPAR $y$ is likely to be the predominant receptor regulating the differentiation of white fat, PPAR $\gamma$ and PPAR $\alpha$ may both contribute to the development of brown fat.

Given that PPAR $\gamma$ and PPAR $\alpha$ are pharmacologically distinct, our results suggest that there may be several different lipid signaling pathways involved in the regulation of adipocyte gene expression and differentiation. A novel pathway involving prostaglandin $\mathrm{J} 2$ metabolites recently has been implicated in the activation of PPAR $\gamma$ (Forman et al. 1995; Kliewer et al. 1995). Although true ligands for PPAR $\alpha$ have not been described, this receptor is activated by high concentrations of dietary fatty acids (Keller et al. 1993). $\beta$-Adrenergic stimulation of brown adipose cells leads to the generation of free fatty acids and the induction of UCP. It is possible that PPAR $\alpha$ has a role in the expression of UCP and other genes linked to brown fat thermogenesis.

Finally, it must be remembered that hormones play a great role in the promotion of adipogenesis. Insulin, insulin-like growth factor (IGF-1), growth hormone, glucocorticoids, and catecholamines all affect fat differentiation in vitro and in vivo. The activity of all three isoforms of PPAR may be modified by one or more of these factors and make them more or less adipogenic. A full appreciation of the role of the PPARs in fat differentiation and lipogenesis must include a greater understanding of hormonal influences and the identity and quantity of their respective endogenous ligands.

\section{Materials and methods}

\section{Transient transfection assay}

Luciferase assays were performed as described previously (Forman et al. 1995, and references therein|. CV-1 cells were grown in Dulbecco's modified Eagle medium (DMEM) containing 10\% resin-charcoal-stripped bovine calf serum. One day prior to transfection, cells were plated to $50 \%-80 \%$ confluence. Cells were transfected in phenol-red free DMEM-FBS (DMEM containing $10 \%$ resin-charcoal stripped fetal bovine serum/ by lipofection using $N-\{1-(2,3$-dioleoyloxy|propyl|- $N, N, N$-ammonium methylsulfate according to the manufacturer's instructions (DOTAP, Boehringer Mannheim). After $2 \mathrm{hr}$, the liposomes were removed and cells were treated for $\sim 40 \mathrm{hr}$ with phenol-red free DMEM-FBS alone or with the indicated compounds. After exposure to PPAR activators, cells were harvested and assayed for luciferase and $\beta$-galactosidase activity.

\section{Plasmids}

Construction of the mammalian expression vectors used in the transfection assays, $\mathrm{pCMX}-\mathrm{PPAR} \alpha, \mathrm{pCMX}-\mathrm{PPAR} \gamma$, and $\mathrm{pCMX}-$

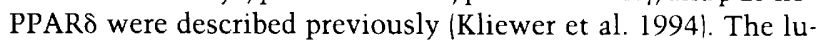

ciferase reporter gene $\mathrm{PPRE}_{3} /$ thymidine kinase/luciferase (PPRE F $_{3}$ TK-LUC) has been described (Forman et al. 1995). The retroviral constructs containing cDNAs encoding murine PPAR $\gamma(\mathrm{pBabe-PPAR} \gamma \mathrm{M} 1)$ and C/EBP $\alpha(\mathrm{pLJ}-\mathrm{C} / \mathrm{EBP} \alpha)$ were described previously (Tontonoz et al. 1994c). cDNAs encoding amino acid residues $1-440$ of murine PPAR $\delta$ and amino acid residues 88-469 of murine PPAR $\alpha$ were derived from pCMXPPAR $\alpha$ and pCMX-PPAR (Kliewer et al. 1994) by PCR and cloned as Sall fragments into the Sall site of pBabe-Puro (Pear et al. 19931. The PPAR $\gamma$ cDNA sequences from pBabe-PPAR $\gamma M 1$ and pBabe-PPAR $\alpha$ were derived by PCR and inserted into pCMX and pCRII (Invitrogen) for in vitro transcription and translation.

\section{Stable cell lines}

Stable cell lines expressing adipogenic transcription factors were derived as described previously (Tontonoz et al. 1994c). BOSC 23 cells were cultured in $90 \cdot \mathrm{mm}$ dishes and transfected at $80 \%$ confluence by calcium phosphate coprecipitation with 15 $\mu \mathrm{g}$ of $\mathrm{pBabe}$ - or $\mathrm{pLJ}$-derived expression vector as described (Pear et al. 19931. Viral supernatants were collected $48 \mathrm{hr}$ after transfection. NIH-3T 3 cells at $50 \%$ confluence in $90-\mathrm{mm}$ dishes were infected with equal titers of recombinant virus. The supernatants were applied in DMEM containing $10 \%$ cosmic calf serum (Hyclonel and $4 \mu \mathrm{g} / \mathrm{ml}$ of polybrene. Cells were split 1:4, $24 \mathrm{hr}$ after infection and plated in DMEM containing $10 \%$ calf serum and either $2 \mu \mathrm{g} / \mathrm{ml}$ of puromycin or $400 \mu \mathrm{g} / \mathrm{ml}$ of neomycin to select infected cells. Cell lines expressing both $\mathrm{C} / \mathrm{EBP} \alpha$ and a PPAR isoform were established by infecting NIH-C/EBP $\alpha-p L J$ cells with virus containing a pBabe-PPAR expression vector.

\section{Cell culture and induction of differentiation}

Following drug selection, virally infected stable cell lines were cultured to confluence in differentiation medium [DMEM containing $10 \%$ cosmic calf serum (Hyclone), $5 \mu \mathrm{g} / \mathrm{ml}$ of insulin, and 1 n. triiodothyronine]. At confluence, cells were treated with 1 p.l dexamethasone for $24 \mathrm{hr}$. PPAR activators were added to the media at confluence in a minimal volume $(<5 \mu l)$, where indicated. Pioglitazone $15-[4-[2-[5-e t h y l-2 \cdot$ pyridyl $\mid-$ ethoxy|benzyl]-2,4-thiazolidinedione) (UpJohn), and Wy14,643 [4-chloro-16-12,3-xylindino)-2-pyrimidinylthiolacetic acid] [Chemsyn) were dissolved in DMSO, $15 \mathrm{~d}-\mathrm{J} 2$ (Cayman Chemical) in methyl acetate, and carbacyclin (Biomol), and 2-bromopalmitate (Sigma) in ethanol. Cells were refed every 24 hr. At 5 or 7 days postconfluence as indicated, either total RNA was isolated or cells were fixed and stained with Oil Red O/Green and Kehinde 1974l.

\section{RNA and protein analysis}

Total RNA was isolated from cultured cells by guanidine isothiocyanate extraction |Chirgwin et al. 1979|. RNA was denatured in formamide and formaldehyde and electrophoresed through formaldehyde-containing agarose gels as described ( $\mathrm{Ma}$ niatis et al. 1989). RNA was blotted to BioTrans nylon (ICN Pharmaceuticalsl, and membranes were cross-linked, hybridized, and washed as directed by the manufacturer. To control for equivalency of RNA loading and transfer, all blots were hybridized with the cDNA for human acid ribosomal phosphoprotein PO [36B4 (Laborda 1991)]. cDNA probes were labeled with $\left[\alpha-{ }^{32} \mathrm{P} \mid \mathrm{dCTP} / 6000 \mathrm{Ci} / \mathrm{mmole}\right)$ by the random-priming method (Fineberg and Vogelstein 1984) to a specific activity of at least $10^{9} \mathrm{cpm} / \mu \mathrm{g}$.

Nuclear extracts were obtained from virally transduced NIH- 
3T3 cells as described previously (Tontonoz et al. 1994b) and subjected to Western blot analysis with a polyclonal anti-PPAR antibody raised against a peptide of a sequence in the DNAbinding domain that is conserved in all three isoforms (Affinity Bioreagents, Inc.). The proteins were separated on a $10 \%$ polyacrylamide-SDS gel, and transferred to Immobilon $P$ membrane (Millipore). Immunodetection was performed with ECL reagents (Amersham, Inc.) according to the manufacturer's directions.

\section{Electorphoretic mobility shift assays}

In vitro-translated RXR $\alpha$ and PPARs were obtained by transcribing and translating the PCMX-RXR $\alpha, \mathrm{pCMX}-\mathrm{PPAR} \gamma \mathrm{Ml}$, pCRII-PPAR $\alpha$, and pCMX-PPAR $\delta$ expression plasmids using the TNT T7-coupled reticulocyte lysate system (Promega). Proteins were quantitated using parallel $\left[{ }^{35} \mathrm{~S}\right]$ methionine-labeled reactions. DNA mobility retardation assays were performed as described (Graves et al. 1991) with the reactions containing equal amounts of in vitro translated products in $3 \mu \mathrm{l}$ of reticulocyte lysate, $20 \mathrm{~mm}$ HEPES at $\mathrm{pH} 7.9,150 \mathrm{~mm} \mathrm{NaCl}, 5 \%$ glycerol, and $0.5 \mu \mathrm{g}$ of poly [d(I-C)] (Pharmacia). DNA-protein complexes were resolved from free probe on a $5 \%$ polyacrylamide gel, which was dried and exposed to film The autoradiograph was digitally scanned, and specifically shifted probe was quantitated using NIH-Image v1.44.

\section{Acknowledgments}

We thank Rolf Kletzien (UpJohn) for supplying pioglitazone. We are also indebted to members of the Spiegelman laboratory for helpful discussions. R.M.E. is an investigator of the Howard Hughes Medical Institute at the Salk Institute for Biological Sciences. This work was supported by National Institutes of Health research grant DK-31405 (B.M.S.), the Howard Hughes Medical Institute (R.M.E.), National Research Service Awards DK-09090 (to R.P.B.) and T32 GM07753 (to P.T.), and the Tobacco-Related Disease Research Program (B.M.F.).

The publication costs of this article were defrayed in part by payment of page charges. This article must therefore be hereby marked "advertisement" in accordance with 18 USC section 1734 solely to indicate this fact.

\section{References}

Amri, E.-Z., F. Bonino, G. Ailhaud, N.A. Abumrad, and P. Grimaldi. 1995. Cloning of a protein that mediates transcriptional effects of fatty acids in preadipocytes. I. Biol. Chem. 270: 2367-2371.

Beck, F., S. Plummer, P.V. Senior, S. Byrne, S. Green, and W.J. Brammar. 1992. The ontogeny of peroxisome proliferatoractivated receptor gene expression in mouse and rat. Proc. $R$. Soc. Lond. Ser. B: Biol. Sci. 247: 83-87.

Cao, Z., R.M. Umek, and S.L. McKnight. 1991. Regulated expression of three C/EBP isoforms during adipose conversion of 3T3-L1 cells. Genes \& Dev. 5: 1538-1552.

Catalioto, R.-M., D. Gaillard, J. Maclouf, G. Ailhaud, and R. Negrel. 1991. Autocrine control of adipose cell differentiation by prostacyclin and PGF2a. Biochim. Biophys. Acta 1091: 364-369.

Chirgwin, J. M., A.E. Przbyla, R.J. MacDonald, and W.J. Rutter. 1979. Isolation of biologically active ribonucleic acid from sources enriched in ribonuclease. Biochemistry 18: 5294 5299.

Christy, R.J., V.W. Yang, J.M. Ntambi, D.E. Geiman, W.M.
Landschulz, A.D. Friedman, Y. Nakabeppu, T.J. Kelly, and M.D. Lane. 1989. Differentiation-induced gene expression in 3T3-Ll preadipocytes: CCAAT/enhancer binding protein interacts with and activates the promoters of two adipocytespecific genes. Genes \& Dev. 3: 1323-1335.

Christy, R.J., V.W. Yang, J.M. Ntambi, D.E. Geiman, W.H. Landschulz, and M.D. Lane. 1991. CCAAT/enhancer binding protein gene promoter: Binding of nuclear factors during differentiation of 3T3-Ll preadipocytes. Proc. Natl. Acad. Sci. 88: 2593-2597.

Cornelius, P., O.A. MacDougald, and M.D. Lane. 1994. Regulation of adipocyte development. Annu. Rev. Nutr. 14:99129.

Fineberg, A.P. and B. Vogelstein. 1984. A technique for radiolabeling DNA restriction fragments to high specific activity. Anal. Biochem. 137: 266-267.

Forman, B.M., P. Tontonoz, J. Chen, R.P. Brun, B.M. Spiegelman, and R.M. Evans. 1995. 15-deoxy- $\Delta^{12,14}$-prostaglandin J2 is a ligand for the adipocyte determination factor PPARy. Cell 83: 803-812.

Freytag, S.O., D.L. Paielli, and J.D. Gilbert. 1994. Ectopic expression of the CCAAT/enhancer-binding protein $\alpha$ promotes the adipogenic program in a variety of mouse fibroblastic cells. Genes \& Dev. 8: 1654-1663.

Gottlicher, M., E. Widmark, Q. Li, and J.A. Gustafsson. 1992. Fatty acids activate a chimera of the clofibric acid-activated receptor and the glucocorticoid receptor. Proc. Natl. Acad. Sci. 89: 4653-4657.

Graves, R.A., P. Tontonoz, S.R. Ross, and B.M. Spiegelman. 1991. Identification of a potent adipocyte-specific enhancer: Involvement of an NF-1-like factor. Genes \& Dev. 5: 428437.

Graves, R.A., P. Tontonoz, and B.M. Spiegelman. 1992. Analysis of a tissue-specific enhancer: ARF6 regulates adipogenic gene expression. Mol. Cell. Biol. 12: 1202-1208.

Green, H. and O. Kehinde. 1974. Sublines of mouse 3T3 cells that accumulate lipid. Cell 1: 113-116.

- 1976. Spontaneous heritable changes leading to increased adipose conversion in 3T3 cells. Cell 7: 105-113.

Gulick, T., S. Cresci, T. Caira, D.D. Moore, and D.P. Kelly. 1994. The perosixome proliferator-activated receptor regulates mitochondrial fatty acid oxidative enzyme gene expression. Proc. Natl. Acad. Sci. 91: 11012-11016.

Herrera, R., H.S. Ro, G.S. Robinson, K.G. Xanthopoulos, and B.M. Spiegelman. 1989. A direct role for C/EBP and the AP-1 binding site in gene expression linked to adipocyte differentiation. Mol. Cell. Biol. 9: 5331-5339.

Hu, E., P. Tontonoz, and B.M. Spiegelman. 1995. Transdifferentiation of myoblasts by the adipogenic transcription factors PPAR $\gamma$ and C/EBPa. Proc. Natl. Acad. Sci. 92: 9856-9860.

Isseman, I. and S. Green. 1990. Activation of a member of the steriod hormone receptor superfamily by peroxisome proliferators. Nature 347: 645-649.

Keller, H., C. Dreyer, J. Medin, A. Mahfoudi, K. Ozato, and W. Wahli. 1993. Fatty acids and retinoids control lipid metabolism through activation of peroxisome proliferator-activated receptor-retinoid X receptor heterodimers. Proc. Natl. Acad. Sci. 90: 2160-2164.

Kliewer, S.A., B.M. Forman, B. Blumberg, E.S. Ong, U. Borgmeyer, D.J. Mangelsdorf, K. Umesono, and R.M. Evans. 1994. Differential expression and activation of a family of murine peroxisome proliferator-activated receptors. Proc. Natl. Acad. Sci. 91: 7355-7359.

Kliewer, S.A., J.M. Lenhard, T.M. Wilson, I. Patel, D.C. Morris, and J.M. Lehmann. 1995. A prostaglandin J2 metabolite binds peroxisome proliferator-activated receptor $\gamma$ and pro- 
motes adipocyte differentiation. Cell 83: 813-819.

Krey, G., A. Mafoudi, and W. Wahli. 1995. Functional interactions of peroxisome proliferator-activated receptor, retinoid$\mathrm{x}$-receptor, and $\mathrm{Spl}$ in the transcriptional regualtion of the acyl-coenzyme-A oxidase promoter. Mol. Endocrinol. 9: 219-231.

Laborda, J. 1991. 36B4 cDNA used as an estradiol-independent mRNA control is the cDNA for human acidic ribosomal phosphoprotein PO. Nucleic Acids Res. 19: 3998.

Lee, S.S., T. Pineau, J. Drago, E.J. Lee, J.W. Owens, D.L. Kroetz, P.M. Fernandez-Salguero, H. Westphal, and F.J. Gonzalez. 1995. Targeted disruption of the $\alpha$-isoform of the peroxisome proliferator-activated receptor gene in mice results in abolishment of the pleiotropic effects of peroxisome proliferators. Mol. Cell. Biol. 15: 3012-3022.

Lehmann, J.M., L.B. Moore, T.A. Smith-Oliver, W.O. Wilkison, T.M. Wilson, and S.A. Kliewer. 1995. An antidiabetic thiazolidinedione is a high affinity ligand for perosixome proliferator-activated receptor $\gamma$ (PPAR $\gamma$ ). I. Biol. Chem. 270: 12953-12956.

Lin, F.-T. and M.D. Lane. 1994. CCAATT/enhancer binding protein alpha is sufficient to initiate the 3T3-Ll adipocyte differentiation program. Proc. Natl. Acad. Sci. 91: 87578761.

Maniatis, T., E.F. Fritsch, and J. Sambrook. 1989. Molecular cloning. A laboratory manual. Cold Spring Harbor Laboratory Press, Cold Spring Harbor, NY.

Namba, T., H. Oida, Y. Sugimoto, A. Kakizuka, M. Negishi, A. Ichikawa, and S. Narumiya. 1994. cDNA cloning of a mouse prostacyclin receptor. Multiple signaling pathways and expression in thymic medulla. J. Biol. Chem. 269: 9986-9992.

Ntambi, J.M., S.A. Buhrow, K.H. Kaestner, R.J. Christy, E. Sibley, T.J. Kelly, and M.D. Lane. 1988. Differentiation induced gene expression in 3T3-L1 preadipocytes. I. Biol. Chem. 263: 17297-17300.

Park, E.A., W.J. Roesler, J. Liu, D.J. Klemm, A.L. Gurney, J.D. Thatcher, J. Shuman, A. Friedman, and R.W. Hanson. 1990. The role of the CAAT/enhancer-binding protein in the transcriptional regulation of the gene for phosphoenolpyruvate carboxykinase (GTP). Mol. Cell. Biol. 10: 6264-6272.

Pear, W.S., G.P. Nolan, M.L. Scott, and D. Baltimore. 1993. Production of high titre, helper-free retroviruses by transient transfection. Proc. Natl. Acad. Sci. 90: 8392-8396.

Ross, S.R., R.A. Graves, A. Greenstein, K.A. Platt, H.-L. Shyu, B. Mellovitz, and B.M. Spiegelman. 1990. A fat-specific enhancer is the primary determinant of gene expression for adipocyte P2 in vivo. Proc. Natl. Acad. Sci. 87: 9590-9594.

Samuelsson, L., K. Stromberg, K. Vikman, G. Bjursell, and S. Enerback. 1991. The CAAT/enhancer binding protein and its role in adipocyte differentiation: Evidence for direct involvement in terminal adipocyte development. EMBO $/$. 10: $3787-3793$.

Schmidt, A., N. Endo, S.J. Rutledge, R. Vogel, D. Shinar, and G.A. Rodan. 1992. Identification of a new member of the steroid hormone receptor superfamily that is activated by a peroxisome proliferator and fatty acid. Mol. Endocrinol. 6: 1634-1641.

Teboul, L., D. Gaillard, L. Staccini, H. Inadera, E.-Z. Amri, and P.A. Grimaldi. 1995. Thiazolidinediones and fatty acids convert myogenic cells into adipose-like cells. $/$. Biol. Chem. 270: 28183-28187.

Tontonoz, P., E. Hu, R.A. Graves, A.I. Budavari, and B.M Spiegelman. 1994a. mPPAR 2 : Tissue-specific regulator of an adipocyte enhancer. Genes \& Dev. 8: 1224-1234.

Tontonoz, P., R.A. Graves, A.I. Budavari, H. Erdjument-Brom- age, M. Lui, E. Hu, P. Tempst, and B.M. Spiegelman. 1994b. Adipocyte-specific transcription factor ARF6 is a heterodimeric complex of two nuclear hormone receptors, PPAR $\gamma$ and RXR $\alpha$. Nucleic Acids Res. 22: 5628-5634.

Tontonoz, P., E. Hu, and B.M. Spiegelman. 1994c. Stimulation of adipogenesis in fibroblasts by PPAR $\gamma 2$, a lipid-activated transcription factor. Cell 79: 1147-1156.

Tontonoz, P., E. Hu, J. Devine, E.G. Beale, and B.M. Spiegelman. 1995. PPARy2 regulates adipose expression of the phosphoenolpyruvate carboxykinase gene. Mol. Cell. Biol. 15: 351357.

Tugwood, I.D., I. Isseman, R.G. Anderson, K.R. Bundell, W.L. McPheat, and S. Green. 1992. The mouse peroxisomal proliferator activated receptor recognizes a response element in the 5 ' flanking sequence of the rat acyl CoA oxidase gene. EMBO /. 11: 433-439.

Umek, R.M., A.D. Friedman, and S.L. McKnight. 1991. CCAAT/enhancer binding protein: A component of a differentiation switch. Science 251: 288-292.

Vassaux, G., D. Gaillard, G. Ailhaud, and R. Negral. 1992. Prostacyclin is a specific effector of adipose cell differentiation. Its dual role as a cAMP and $\mathrm{Ca} 2{ }^{*}$-elevating agent. J. Biol. Chem. 267: 11092-11097.

Wu, Z., Y. Xie, N.L.R. Bucher, and S.R. Farmer. 1995. Conditional ectopic expression of C/EBPB in NIH-3T3 cells induces PPAR $\gamma$ and stimulates adipogenesis. Genes \& Dev. 9: 2350-2363.

Yeh, W.-C., Z. Cao, M. Classon, and S.L. McKnight. 1995. Cascade regulation of terminal adipocyte differentiation by three members of the C/EBP family of leucine zipper proteins. Genes \& Dev. 9: 168-181.

Yu, K., W. Bayona, C.B. Kallen, H.P. Harding, C.P. Ravera, G. McMahon, M. Brown, and M.A. Lazar. 1995. Differential activation of peroxisome proliferator-activated receptors by eicosanoids. I. Biol. Chem. 270: 23975-23983.

Zhu, Y., C. Qi, J.R. Korenberg, X.-N. Chen, D. Noya, and M.S. Rao. 1995. Structural organization of mouse peroxisome proliferator-activated receptor $\gamma(\operatorname{mPPAR} \gamma)$ gene: Alternative promoter use and different splicing yield two mPPAR $\gamma$ isoforms. Proc. Natl. Acad. Sci. 92: 7921-7925. 


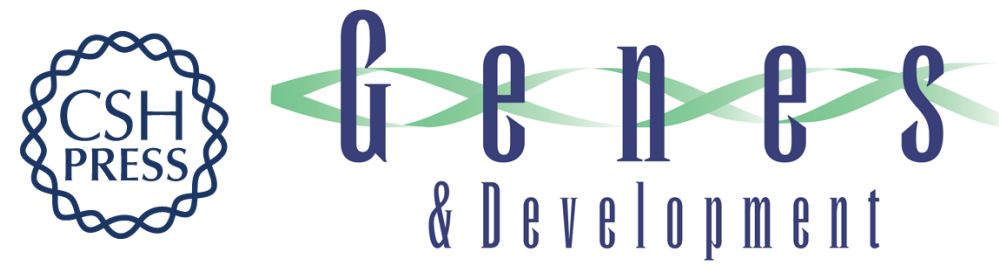

\section{Differential activation of adipogenesis by multiple PPAR isoforms.}

R P Brun, P Tontonoz, B M Forman, et al.

Genes Dev. 1996, 10:

Access the most recent version at doi:10.1101/gad.10.8.974 $\begin{array}{ll}\text { References } & \begin{array}{l}\text { This article cites } 47 \text { articles, } 29 \text { of which can be accessed free at: } \\ \text { http://genesdev.cshlp.org/content/10/8/974.full.html\#ref-list-1 }\end{array}\end{array}$

License

Email Alerting Receive free email alerts when new articles cite this article - sign up in the box at the top Service right corner of the article or click here.

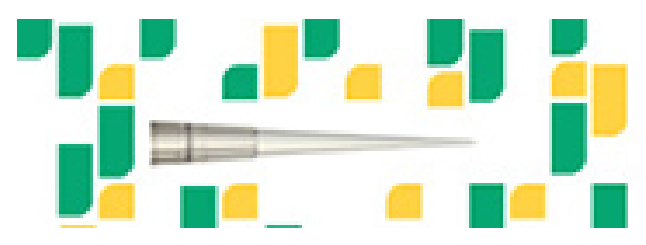

Focused on your science.

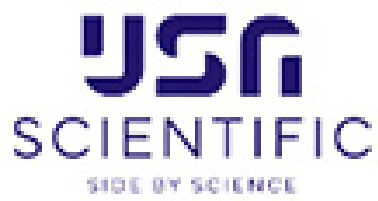

Copyright (c) Cold Spring Harbor Laboratory Press 